\title{
ANALYSIS OF LACTIC AND HEMATOCRIT LEVELS OF BLOOD STORAGE IN THE DR. WAHIDIN SUDIROHUSODO GENERAL HOSPITAL BLOOD BANK
}

\author{
Rysna Wahyu, Asvin Nurulita, Rachmawati Muhiddin \\ Department of Clinical Pathology, Faculty of Medicine, Hasanuddin University/Wahidin Sudirohusodo Hospital, Makassar, Indonesia. \\ E-mail: rysnawahyu@gmail.com
}

\begin{abstract}
The components of Packed Red Cells (PRC) are transfused to patients in order to repair oxygen transportation to tissues. The blood is stored at $2-6^{\circ} \mathrm{C}$ to delay red blood cells metabolism during storage. Red blood cells undergo structural and functional changes biochemically, which affect their viability and function. This study was aimed to analyze the levels of lactate acid and hematocrit $(\mathrm{Ht})$ of blood stored in the Wahidin Sudirohusodo General Hospital Blood Bank, Makassar. This study was a prospective cohort study with time-series design. Samples were taken from fresh blood PRC which were moved to transfer bag for approximately $20 \mathrm{~mL}$, then stored in the refrigerator. Lactic acid and hematocrit levels were assessed with spectrophotometry and flow cytometry methods on day 1, day 4, and day 8 of storage in the Dr. Wahidin Sudirohusodo General Hospital Blood Bank. Statistical tests used were Friedman and Wilcoxon. Statistical results are significant if $p<0.05$. Total samples were 15 fresh blood PRC. Friedman statistical test showed a significant difference in lactic level $(p<0.001)$ and hematocrit level $(p=0.012)$ on day 1 , day 4 , and day 8 of storage. Wilcoxon test showed significantly higher lactic level between day 4 and day $1(p<0.01)$; day 8 and day $1(p<0.01)$; day 4 and day 1 of storage $(p<0.01)$. Hematocrit level between day 4 and day $1(p<0.05)$; day 8 and day 1 ( $p<0.05)$ were significantly higher; day 8 and day 4 of storage $(p>0.05)$ showed insignificant difference. Results showed that lactic and hematocrit levels of stored PRC were increased according to storage duration. Packed red cells blood is recommended to be given in $<6$ days for lower acidosis risk. Further studies are also recommended with a shorter interval of assessment and bigger sample size.
\end{abstract}

Key words: Lactic, hematocrit, stored blood, packed red cells

\section{INTRODUCTION}

Blood transfusion is the process of removing Whole Blood (WB) or blood components from the donor to the recipient to improve the ability of oxygen transport to the tissues, increase the platelet count, or improve blood clotting according to the needs of the patients receiving the donor. Blood for transfusions based on storage duration is divided into; Fresh blood is blood aged six hours after collection; New blood is blood aged longer than six hours to six days after blood collection from a donor; Stored blood is blood older than six days after collection from a donor at optimum temperature. The temperature for blood or blood component storage should always be monitored; The optimal temperature for erythrocyte storage is $2-6^{\circ} \mathrm{C}$. Packed red cells are the most widely used blood component in the world. Red blood cells are the most important component of PRC. ${ }^{1,2}$

Available anticoagulants in the blood bag are Citrate Phosphate Dextrose Adenine (CPDA- 1 ) of 49 $\mathrm{mL}$ for $350 \mathrm{~mL}$ of complete blood. The contents contained in $100 \mathrm{~mL}$ of CPDA-1 are $0.299 \mathrm{~g}$ of citric acid (anhydrous); $2.63 \mathrm{~g}$ of sodium citrate (dihydrate); $0.222 \mathrm{~g}$ of Monobasic Sodium Phosphate (monohydrate); $3.19 \mathrm{~g}$ of Dextrose (monohydrate); and $0.0275 \mathrm{~g}$ of Adenine. The citrate compound contained in the blood bag is useful for preventing coagulation by binding calcium in the donor plasma. Phosphate serves as a buffer to maintain blood $\mathrm{pH}$ and prevents a decrease of 2,3 Diphosphoglycerate (DPG) in which the 2,3 DPG serves to facilitate erythrocyte function as an oxygen transporter. Dextrose is also added to the blood bag to meet the energy demands of cells acting as substrates for producing ATP. Adenine works for the regeneration of Adenosine Triphosphate (ATP) so that blood stored at $2-6^{\circ} \mathrm{C}$ can last up to 35 days from blood collection. During the storage process, the blood cells undergo metabolic changes. Thus care should be put in in-vitro storage in an attempt to reduce the changes that occur in red blood cells during storage since the in-vitro atmosphere is very different from in-vivo. ${ }^{1,3-5}$

In normal red blood cell metabolism, glycolysis 
(the breakdown of glucose) is the sole energy source for red blood cells. The red blood cells do not have mitochondria and depend entirely on glycolysis for energy needs. Red blood cells generate energy through the anaerobic glycolysis pathway, one glucose molecule through anaerobic glycolysis produces 2 ATPs and two lactates as the result of glycolytic metabolism. Lactate, as the end product of red blood cell metabolism has increased during storage. Hematocrit or compressed red blood cell volume in stored blood may increase due to morphological changes in red blood cells during storage. ${ }^{6,7}$

In Blood Bank, blood is stored at temperatures between $2-6^{\circ} \mathrm{C}$, which can slow the metabolism of red blood cells and allow blood to survive during storage in blood banks. Red blood cells will undergo structural and functional changes biochemically even at temperatures of $2-6^{\circ} \mathrm{C}$, which affect the viability and function of red blood cells due to different atmospheres compared to in-vivo. This change is called storage lesion, which is a decrease of adenosine 5 '-triphosphate (ATP) concentration and 2,3 Diphosphoglycerate (DPG), decreased blood pH, increased potassium and lactate concentration, changes in erythrocytes form, loss of erythrocyte vitality, and hemolysis. ${ }^{89}$ The preservative solution aims to minimize the effects of such biochemical changes and maximize the storage time of blood components. Storage lesion causes red blood cell viability to decrease, therefore it cannot be transfused. ${ }^{5,6,8}$

Research conducted by Adias et al. found an increase in hematocrit in the first week of storage. Another study by Gerda et al. showed that in the first seven days of lactate increasing and increasing over time of storage. Researchers are interested in examining changes in lactate and hematocrit levels in stored blood based on storage periods. ${ }^{9-11}$

This study was aimed to analyze the levels of lactate acid and hematocrit $(\mathrm{Ht})$ of blood stored in the Wahidin Sudirohusodo General Hospital Blood Bank, Makassar.

\section{METHODS}

This is a prospective cohort study with time series design conducted from April 2018 by taking samples from packed red cells (PRC) blood bags in the Dr. Wahidin Sudirohusodo General Hospital Makassar Blood Bank. The population of the samples was all new blood of PRC that was stored in Blood Bank, and the samples were the new blood of PRC that was stored in Blood Bank. The dates of sampling were recorded on the blood bags.

Fifteen samples were taken from new blood PRCs which were transferred into the PRC transfer bag for $\pm 20 \mathrm{~mL}$ then stored in the refrigerator. The samples were placed into the tube, then the hematocrit level was assessed. The samples on the other tubes were centrifuged at $3000 \mathrm{rpm}$ for 15 minutes. The supernatant was inserted into the sample cup and lactate levels were assessed at the Clinical Pathology Laboratory Installation on the $1^{\text {st }}$ day, the $4^{\text {th }}$ day and the $8^{\text {th }}$ day of storage at the Blood Bank. Examination of lactate concentration was performed using spectrophotometry method with ABX Pentra 400, and hematocrit level was performed using flow cytometry method with Sysmex XT-2000i Hematology Analyzer. Ethical approval was obtained from the Medical Research Ethics Commission of Hasanuddin University Medical Faculty/Dr. Wahidin Sudirohusodo General Hospital/Hasanuddin University Hospital, Makassar No. 253/H4.8.4.5.31/PP36-KOMETIK/2018.

Data analysis was done using SPSS statistical program. The statistical tests used were the Friedman test and Wilcoxon test. Statistical test results are significant if the $p$-value $<0.05$.

\section{RESULTS AND DISCUSSION}

Based on the results of the study that has been conducted in the Dr. Wahidin Sudirohusodo Makassar General Hospital Blood Bank during April 2018, the data obtained were 15 new blood PRC samples that were stored with predetermined sample selection criteria (Table 1).

Table 1. Sample characteristics

\begin{tabular}{ccc}
\hline Variable & n (15) & \% \\
\hline Blood type & & \\
A & 4 & 26.7 \\
B & 3 & 20.0 \\
O & 3 & 20.0 \\
AB & 5 & 33.3 \\
\hline
\end{tabular}

Source: Primary data

Table 1 shows the characteristics of new blood PRC that were stored in the blood bank according to blood type. The data in Table 1 shows that 15 new blood samples were from blood type $A, B, O$, and $A B$, each of which consisted of 4 blood type $A(26.7 \%)$, 3 blood type B (20.0\%), 3 blood type O (20.0\%), and 5 blood type $A B(33.3 \%)$. 
Table 2. Comparison of lactate acid and hematocrit levels $(n=15)$

\begin{tabular}{cccccc}
\hline Parameter & Range & Median & Mean & SD & p \\
\hline Lactate $(\mathrm{mg} / \mathrm{dL})$ & & & & & \\
Day 1 & $38.8-90.7$ & 55.6 & 55.9 & 13.2 & \\
Day 4 & $81.7-183.3$ & 100.4 & 105.3 & 25.0 & $<0.001^{\mathrm{a}^{\star}}$ \\
& & & & & $0.001^{\mathrm{b}^{\star \star}}$ \\
Day 8 & $106.6-213.3$ & 132.0 & 135.6 & 26.9 & $0.001^{1^{\star \star}}$ \\
& & & & & $0.001^{\mathrm{d}^{\star \star}}$ \\
Hematocrit (\%) & $19.1-4.0$ & 37.1 & 36.1 & 6.9 & $0.012^{\mathrm{a}^{\star}} 0.022^{\mathrm{b}^{\star \star}}$ \\
Day 1 & $20.1-47.1$ & 38.3 & 37.1 & 7.0 & $0.044^{4^{\star \star}}$ \\
Day 4 & $20.6-45.8$ & 38.6 & 37.2 & 6.8 & $0.729^{\mathrm{d}^{\star \star}}$ \\
Day 8 & & & & & \\
\hline
\end{tabular}

*Friedman test

**Wilcoxon Signed Rank Test

a Day 1 vs. Day 4 vs. Day 8 bDay 1 vs. Day 4 cDay 1 vs. Day 8 dDay 4 vs. Day 8

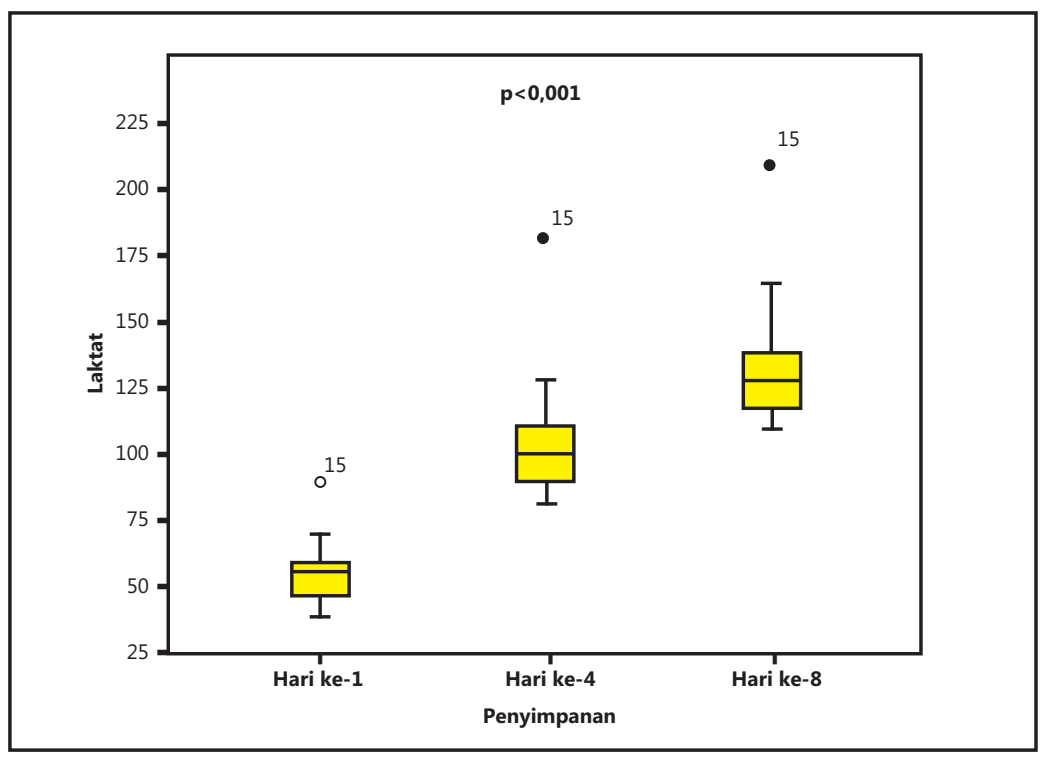

Figure 1. Comparison of lactate levels in PRC stored blood (lactate normal range: 0-20 mg/dL)

Table 2 shows the results of lactate and hematocrit examinations on the $1^{\text {st }}, 4^{\text {th }}$, and $8^{\text {th }}$ day of PRC blood storage at Blood Bank. There were statistically significant differences of mean lactate levels at the 1st, 4th, and 8th day of storage $(p<0.001)$, i.e. the lowest on day $1(55.9 \pm 13.2)$ compared to day $4(105.3 \pm 25.0)$, and day 8 (135.6 \pm 26.9$)$. The results also showed that lactate levels on day 4 were significantly higher compared to day $1(p<0.01)$ and lactate levels on day eight were significantly higher than on day 1 and $4(p<0.01$, respectively) (Figure 1 ).

The data in Table 2 also showed that there was statistically significant difference of mean hematocrit on the storage of day 1,4 , and $8(p=0.012)$, i.e. the lowest was on day $1(36.1 \pm 6.9)$ compared to day 4
(37.1 \pm 7.0$)$, and day $8(37.2 \pm 6.8)$. The results also showed that the hematocrit level on day 4 was significantly higher than on day 1 ( $p<0.05$ ), hematocrit level on day 8 was significantly higher than on day $1(p<0.05)$, and hematocrit level at day 8 did not differ significantly with hematocrit level at day 4 ( $p>0.05$ ) (Figure 2 ).

The results showed that there were statistically significant differences in lactate levels $(p<0.001)$ and hematocrit levels $(p=0.012)$. The results of this study indicated that there was an increase in lactate levels in the stored PRC in line with storage duration. During storage from day 1 and day 4 , day 4 and day 8 , and day 1 and day 8 , there were significant increases $(p<0.01)$. Levels of stored PRC hematocrit along storage time showed that hematocrit levels on day 


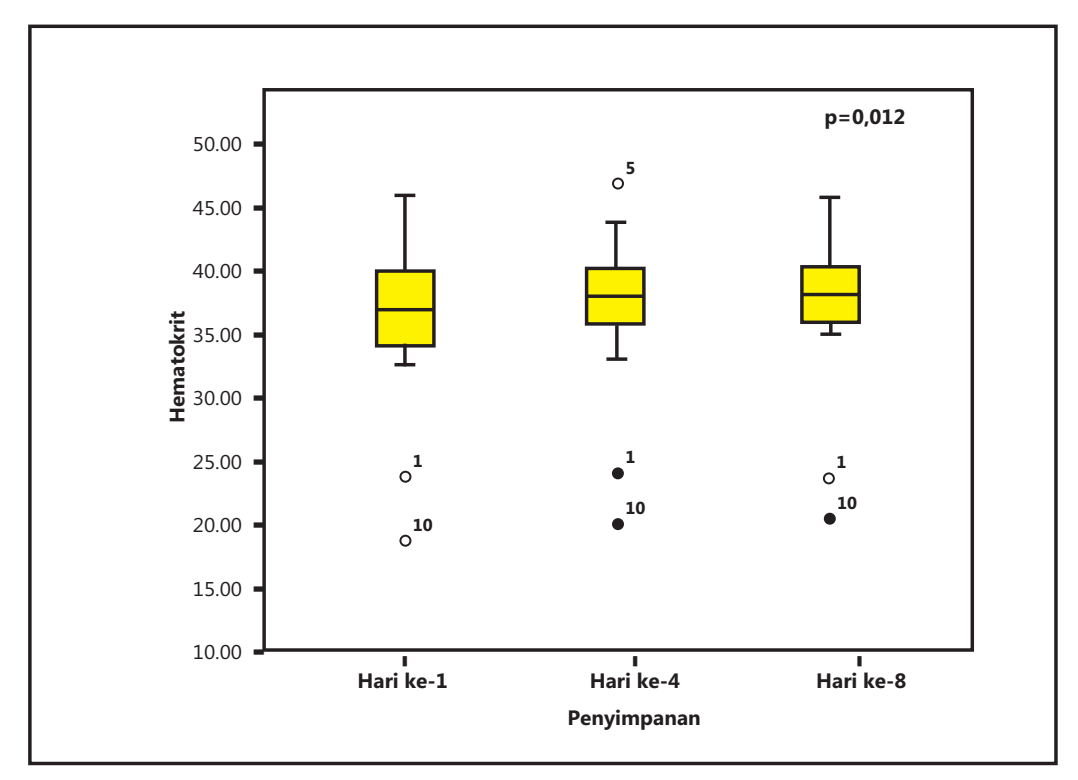

Figure 2. Comparison of hematocrit levels in stored PRC (hematocrit normal range: $37-48 \%$ )

four were significantly higher compared to day 1 $(p<0.05)$, hematocrit levels on day eight were significantly higher compared to day $1(p<0.05)$, and hematocrit levels on day 8 did not differ significantly with hematocrit levels on day four $(p>0.05)$.

Mature red blood cells have no nuclei and mitochondria. Thus they are unable to produce energy through the Krebs cycle (oxidative pathway). The red blood cells are completely dependent on other metabolic pathways, especially The Embden-Meyerhof pathway (glycolysis), in this pathway ATP is produced by anaerobic glucose breakdown; The Hexose Monophosphate pathway, which produces NADPH to protect red blood cells from oxidative lesion; and The Rapoport-Luebering pathway, for the production of 2,3-diphosphoglycerate (2,3-DPG) which plays a role in the regulation of oxygen affinity. ${ }^{9,12}$

The energy source of blood cells comes from anaerobic glycolysis that produces ATP molecules and pyruvic acid, and then pyruvic acid will be converted into lactate as the final product of red blood cell metabolism. Lactate increases during storage. This study showed that lactate levels were significantly higher than on day 1 and 4 . A study conducted by Leitner et al. found lactate increase and continued to increase along with storage duration. The occurrence of lactate accumulation throughout the storage period indicates that the glycolysis process does not stop. The accumulation of lactate can aggravate the condition of the recipient body that has acid-base balance disturbance. $^{8.9}$
In maintaining an erythrocyte vitality and a sodium-potassium pump, ATP is required, but storage time in the refrigerator will cause a decrease in ATP levels resulting in the failure of ion pump in cells and cell membrane damage resulting in cell morphological changes. This results in changes in hematocrit levels in blood cells. This study showed that hematocrit levels on day four were significantly higher than on day one. The shape and size of erythrocytes began to change during storage due to erythrocyte swelling and weakening of the erythrocyte cytoskeleton. The erythrocyte membrane also becomes unstable, which changed the erythrocyte morphology from biconcave to spherocytes, decreased lipid content, and increased cell rigidity. Hematocrit levels on day eight did not differ significantly with hematocrit levels on day four, red blood cells still experience morphological changes, although not significant and also some of the erythrocytes were already undergone lysis. Adias et al. found an increase in hematocrit in the first week of storage and a study by Mustafa et al., also found a significant increase in hematocrit during storage..$^{10,11}$ Red blood cells that are damaged by erythrocyte membrane and ion pump failure can result in deformability of erythrocytes decreased to hemolysis so that if given into the recipient body with red blood cell function to pass microvascular is decreased which can cause systemic oxygen delivery deficit. Adenosine triphosphate plays a role in maintaining the red cell phospholipid membrane, but the red blood cells undergo storage lesion during storage. ${ }^{9-11}$ 
Increased lactate levels in stored PRC can affect the recipient's body condition or aggravate the condition of the patient with acidosis. Normal levels of lactate in the blood are $0.6-1.5 \mathrm{mmol} / \mathrm{L}$ or $0-20$ $\mathrm{mg} / \mathrm{dL}$, and the levels of lactate acceptable by the body are about $>2.0-5 \mathrm{mmol} / \mathrm{L}$ or $>18.02-45.05$ $\mathrm{mg} / \mathrm{dL}^{13}$

\section{CONCLUSION AND SUGGESTION}

Lactate and hematocrit levels in stored PRC increased with duration of storage. It is recommended that PRC blood was given $<6$ days so that the risk of acidosis is lower. It is also recommended that further studies with a shorter examination time range and larger sample quantities.

\section{REFERENCES}

1. Sudiono H, Iskandar IGN, Edward H, Halim SL, Santoso R. Transfusi darah. Dalam: Penuntun patologi klinik hematologi. Jakarta, Biro Publikasi Fakultas Kedokteran Ukrida, 2009; 200-9.

2. Bakta IM. Transfusi darah. Dalam: Hematologi klinik ringkas. Jakarta, Penerbit Buku Kedokteran EGC, 2006; 271-3.

3. Prihartini D. Jenis-jenis komponen darah dan indikasi pemberiannya. Dalam: dasar-dasar transfusi darah. Jakarta, Penerbit Fakultas Kedokteran Universitas Padjadjaran, 2011; 49-54.
4. Rudmann SV. Blood banking and transfusion medicine. $2^{\text {nd }}$ Ed., Philadelphia, Churchill Livingstone Elsevier, 2005; 202.

5. Weinstein SM. Plumer's Principle \& practice of intravenous therapy. $8^{\text {th }}$ Ed., Philadelphia, Lippincott Williams \& Wilkins. 2006; 421.

6. Bain BJ, Lewis SM. Basic haematological techniques. In: Practical haematology $11^{\text {th }}$ Ed., Philadelphia, Churchill Livingstone Elsevier, 2012; 41-2.

7. Soebrata RG. Penuntun laboratorium klinik. Jakarta, Dian Rakyat, 2002; 39-42.

8. Hess JR, Beyer GM. Red blood cell metabolism during storage. In: Blood banking and transfusion medicine. $2^{\text {nd }}$ Ed., Philadelphia, Elsevier, 2007; 205-10.

9. Gerda LC, Rach I, Horvath M, Buchta C. Collection and storage of whole blood in autologous blood predeposit in elective surgery programs. International Journal of Surgery, 2006; 4(3): 179-83.

10. Adias TA, Igwe-MB, Jeremiah AZ. Storage related haematological and biomedical changes of CPDA-1 whole blood in a resource-limited setting. Journal of Blood Disorders \& Transfusion. 2012; 3(3): 2155-9864.

11. Mustafa I, Marwani Al, Nasr MK, Kano NA, Hadwan. Time-dependent assessment of morphological changes: Leukodepleted packed red blood cells stored in SAGM. 2016; 2016: 7.

12. Flatt JF, Bawazir WM, Bruce LJ. The involvement of cation leaks in the storage lesion red blood cells. Front Physiol, 2014; 5: 214.

13. W Romy, Suparyatha WR, IGL Sidiartha, Hartawan IN. Mortalitas asidosis metabolik laktat dan nonlaktat di unit perawatan intensif pediatrik RSUP Sanglah. Sari Pediatrik, Denpasar, 2012; 13(5): 351-6. 